myelin sheaths which in culture, as in the animal, were composed of modified neuroglial cell membrane. On removal of the EAE or MS serum, cultures of mammalian CNS tissue were observed to remyelinate.

In addition to those factors directed against the neuroglial cell membrane, the tissue culture model system had also revealed the presence of others which might be directed against the neuronal cell membrane. The evidence consisted of a rapid decrease and finally abolition of bioelectric activity representative of the propagation and transmission of the nervous impulse. In polysynaptic neuronal networks, the block in transmission and the decrease in propagation was also rapidly reversible once the offending serum was removed from the tissue culture environment. The action of these factors was also dependent upon the presence of complement.

Recently, a series of EAE-inoculated animals had been killed serially from day 3 to day 16 after their exposure and their serum and lymph node cells tested for demyelinating activity. Both possessed the ability to demyelinate cultures beginning at approximately the fourth day after exposure to the inoculum.

These findings were discussed in relationship to the experimentally produced disorder and the naturally occurring disease.

\section{PATHOGENESIS OF MULTIPLE SCLEROSIS}

E. J. FIELD (Newcastle upon Tyne) The idea that MS might be infective in origin went back to Pierre Marie (1884) and received powerful impetus from the report by Campbell, Daniel, Porter, Russell, Smith, and Innes (1947) that four of seven research workers investigating swayback of lambs had developed multiple sclerosis. While attempts to transfer the disease had been unsuccessful, the work of Sigurdsson and his school in Iceland (1954) showed that, among sheep at least, some transmissible diseases, such as visna, maedi, and rida might take as long as a quarter or a third of an animal's lifetime to appear. With this possibility in mind, transmission attempts had been made both in sheep (Palsson, Pattison, and Field, 1965) and mice (Field, 1966) over prolonged periods and involving blind passage. Recently a more rapid passage coupled with whole body radiation of the final recipient had succeeded in producing a neurological 음 illness in mice from kuru material (Field, 1968) and the $\bar{Q}$ same technique had been successful in one further case of MS. In all these instances the disease known as scrapie $\mathcal{O}^{+}$ had emerged. A fundamental feature in its pathogenesis was early and marked hypertrophy of astrocytes. The same had been reported by Charcot (1876), Müller (1904), क Anton and Wohlwill (1912), and Jakob (1967) to be the earliest change in multiple sclerosis. The hypothesis might be put forward that the pathogenetic mechanism at work in kuru, scrapie, and Jacob-Creutzfeldt disease $\mathrm{r}$ which leads to marked astroglial hypertrophy (with the $\vec{F}$. character of a benign neoplasia) was also operative in $\stackrel{?}{+}$ multiple sclerosis. In the latter the process was focalized around small veins and when it went on to extreme degree resulted in the well-known, attention-drawing $\frac{\overline{\mathcal{S}}}{\vec{\rho}}$ plaques so readily demonstrable; while in the other $\mathbb{D}$ conditions mentioned the process was more diffuse. The seemingly normal parts of the brain might be more $\infty$ rewarding to study in MS than actual lesions (cf. Herpes $\vec{\circ}$ encephalitis).

The suggestion that a 'slow' infection (with no pre- $\vec{\omega}$ suppositions as to the nature of the agent, cf. Adams and Field, 1968) might be operative in multiple sclerosis did $\vec{\partial}$ not preclude some other mechanism also being at work -for example, an immunological one-which might $\omega_{N}$ account for the continued recurrent activity of the disease iv in some cases.

\section{REFERENCES}

Adams, D. H., and Field, E. J. (1968). Lancet, $2,714$.

Anton, G., and Wohlwill, R. (1912). Z. ges. Neurol. Psychiat., 12, 3ब. Campbell, A. M. G., Daniel, P., Porter, R. J., Russell, W. R., Smit, H. V., and Innes, J. R. M. (1947). Brain, 70, 50.

Charcot, J. M. (1876). Maladies du Système Nerveux, p. 239. Delahay Paris.

Field, E. J. (1966). Brit. med. J., 2, 564.

- (1968). Lancet, 1, 981.

Jakob, A. (1967). Symposium on Multiple Sclerosis, held at Locarno. (Auspices German Multiple Sclerosis Society.)

Marie, P. (1884). Progr. méd. (Paris), 12, 287; 305; 349, and 365.

Müller, E. (1904). Die Multiple Sklerose des Gehirns und Ruckenmarks. هి Fischer: Jena.

Palsson, P. A., Pattison, I. H., and Field, E. J. (1965). Slow Latent and $\mathbb{D}$ Temperate Virus Infections, p. 49. Edited by D. C. Gajdusek, $\vec{\overrightarrow{ }}$ C. J. Gibbs, Jr., and M. Alpers. U.S. Government Printing $\overline{\mathrm{O}}$ Offices: Washington, D.C.

Sigurdsson, B. (1954). Brit. vet. J., 110 (Nos. 7, 8, 9), 255, 307, and 341 . 